\title{
Influence of Polymorphisms of DNA Repair and GST Genes on Genotoxic Damage and Mutagen Sensitivity in Workers Occupationally Exposed to Very Low Doses of Ionizing Radiation
}

\author{
Angela Stufano ${ }^{1}$, Patrizia Chiarappa ${ }^{1}$, Rosanna Bagnulo ${ }^{2}$, Ignazio Drago ${ }^{1}$, \\ Venerando Rapisarda ${ }^{3}$, Caterina Ledda ${ }^{3}{ }^{(0}$, Luigi Vimercati ${ }^{1}{ }^{\circledR}$, Leonarda De Benedictis ${ }^{1}$, \\ Nicoletta Resta ${ }^{2}$, Leonardo Soleo ${ }^{1}$ and Piero Lovreglio ${ }^{1, * \mathbb{D}}$ \\ 1 Interdisciplinary Department of Medicine, Section of Occupational Medicine, University of Bari, 70124 Bari, \\ Italy; stufano.a@gmail.com (A.S.); patriziachiarappa@yahoo.it (P.C.); ignazio.drago@gmail.com (I.D.); \\ luigi.vimercati@uniba.it (L.V.); leonarda.debenedictis@uniba.it (L.D.B.); leonardo.soleo@uniba.it (L.S.) \\ 2 Department of Biomedical Sciences and Human Oncology, Division of Medical Genetics, University of Bari, \\ 70124 Bari, Italy; rosanna.bagnulo@uniba.it (R.B.); nicoletta.resta@uniba.it (N.R.) \\ 3 Department of Clinical and Experimental Medicine, Section of Occupational Medicine, University of Catania, \\ 95131 Catania, Italy; vrapisarda@unict.it (V.R.); cledda@unict.it (C.L.) \\ * Correspondence: piero.lovreglio@uniba.it; Tel.: +39-080-5478-218
}

Received: 25 October 2019; Accepted: 23 November 2019; Published: 28 November 2019

\begin{abstract}
The study investigated the influence of genetic polymorphisms of the enzymes for DNA repair and detoxification of reactive intermediates on spontaneous and bleomycin-induced (BLM) genotoxic damage in 43 workers exposed to very low doses of ionizing radiation (IR) (mean cumulative dose $5.31 \mathrm{mSv}$ ) and 43 subjects with no occupational exposure to IR (controls). In all the subjects examined, the frequency of chromosome aberrations (CAs) and micronuclei (MN), both spontaneous and BLM-induced, the Comet assay parameters (tail intensity), the genotypic variants of the DNA repair enzymes XRCC1 (Arg194Trp, Arg280His, Arg399Gln), XRCC3 (Thr241Met), XPD (Lys751Gln), and of the detoxification enzymes GSTM1 and GSTT1 (null genotype) and BLMH (A1450G) were determined. Among the biomarkers considered, only the frequency of total CAs $(p<0.05)$, and in particular of chromosome breaks $(p<0.01)$, was found to be significantly higher in the exposed workers than the controls. The frequency of spontaneous $\mathrm{MN}$ was higher in subjects with at least one allelic variant in XRCC1 than in carriers of the wild-type, but again only in exposed workers $(p=0.046)$. Linear regression analysis showed a positive dependency of the frequency of spontaneous chromosome breaks on occupational exposure, and a dependency of the frequency of BLM-induced MN negative on occupational exposure and positive on alcohol consumption and the null GSTM1 genotype. In conclusion, the frequency of chromosome breaks seems to be a useful cytogenetic biomarker for exposure to very low doses of IR, while only the combined effect of different gene variants or genetic, occupational, and lifestyle habits factors seems to be able to modulate the genotoxic effect of very low doses of IR.
\end{abstract}

Keywords: chromosome aberrations; micronuclei; mutagen sensitivity

\section{Introduction}

Prolonged occupational exposure to high doses of ionizing radiation (IR) can cause DNA alterations, such as single-strand breaks (SSBs), double-strand breaks (DSBs), damage to purine and pyrimidine bases, and DNA-protein crosslinking, that can result in cell death or neoplastic transformation [1]. 
In fact, IR is classified in group 1 by the International Agency Research on Cancer (IARC) as carcinogenic to humans [2].

Increased genotoxic damage has also been observed in workers with occupational exposure to IR at lower doses than the authorized dose limits, consisting of an increased frequency of chromosome aberrations (CAs) and micronuclei (MN), as compared to control groups with no occupational exposure [3-5]. However, these genotoxic effects were not shown to be correlated to the cumulative dose of IR exposure [6]. The Comet assay also yielded discordant results in regards to increased DNA damage in workers exposed to IR, although no influence was observed when considering specific parameters of oxidative damage to the purine or pyrimidine bases using the Fpg and Endo III enzymes [7-11].

Genetic polymorphisms of the DNA repair enzymes can play a fundamental role in the expression of the effects of exposure to low doses of IR. In this regard, Angelini et al. [4] observed a significant increase in the frequency of $\mathrm{MN}$ in workers exposed to a mean equivalent IR cumulative dose of $40.61 \mathrm{mSv}$, with allelic variants for XRCC1, XRCC3 and XPD, as compared to controls with the same genotype, while Andreassi et al. [12] found an increased frequency of $\mathrm{MN}$ in workers exposed to IR, with allelic variants for XRCC3 compared to workers with the same exposure but with the wild-type genotype.

Polymorphisms of the glutathione-S-transferases (GSTs) genes M1 and T1 also seem to affect DNA damage induced by IR, eliciting a greater susceptibility by interfering with the detoxification processes of the intermediate reactive species produced by the cells in response to the IR effects [13]. Nevertheless, the role of these polymorphisms remains controversial. In fact, Marcon et al. [14] demonstrated a greater frequency of CAs correlated to the GST1 positive phenotype in peripheral lymphocytes of smokers, irradiated in vitro with $\gamma$ rays, while Sakly et al. [15] showed that these polymorphisms do not significantly alter the potential genotoxic effect of IR.

In workers exposed to low doses of IR, chromatid damage induced in peripheral lymphocytes following in vitro exposure to bleomycin (BLM), defined as mutagen sensitivity, can be indicative of individual variability in the response capacity to genotoxic IR actions [16-18]. Individual mutagen sensitivity seems to be influenced by the presence of polymorphisms in enzymes responsible for both the DNA repair and the detoxification of reactive intermediates, as shown in healthy subjects not exposed to IR. Up to now, however, the relation between mutagen sensitivity and the presence of enzyme polymorphisms has never been studied in workers exposed to low doses of IR [19-21].

The aim of this study was, therefore, to verify whether the genotoxic effects and mutagen sensitivity in workers with occupational exposure to very low doses of IR can be modulated by genetic polymorphisms of the enzymes involved in DNA repair and detoxification of reactive intermediates induced by IR.

\section{Materials and Methods}

\subsection{Subjects}

In total, 43 workers with occupational exposure to very low doses of IR (exposed workers) and 43 non exposed subjects (controls), matched for age and resident in the same geographic area, were included in the study. The exposed workers group consisted of 7 industrial radiology technicians and 36 health care workers (doctors, technicians and nurses working in radiology, doctors specialists in radiotherapy, nuclear medicine, general surgery, orthopedics, cardiac surgery, vascular surgery, anesthesia, and intensive care).

All participants were administered a questionnaire probing aspects such as personal characteristics, lifestyle habits, current and past working activities, possible non occupational exposure to other genotoxic agents, radiographic examinations for diagnostic purposes undergone in the last year, medical history, and any ongoing therapy. For exposed workers, the effective dose received to the 
whole body in the last year and in their whole working life (cumulative dose) were calculated from the personal dosimetric data sheets.

Subjects who had undergone radiotherapy or chemotherapy and those affected by cancer were excluded from the study and also, among the exposed workers, those with a history of occupational exposure to IR of less than one year. All enrolled subjects were fully informed about the research aims and features and gave written informed consent to take part before the administration of the questionnaire. The research was conducted in accordance with the Helsinki Declaration. All the data reported in the study were collected in the context of the health surveillance procedures that are mandatory by Italian Law.

\subsection{DNA Damage Biomarkers}

Analyses of the spontaneous and BLM-induced frequency of CAs and MN, and the determination of the Comet assay parameters were done on heparinized peripheral vein blood samples obtained from all the exposed workers and controls. The blood samples were labeled and transported at room temperature to the laboratories, where they were cultured for cytogenetic tests within $24 \mathrm{~h}$ of collection.

\subsection{Analyses of Chromosome Aberrations}

For the CAs analyses, $400 \mu \mathrm{L}$ of whole blood were incubated in $5 \mathrm{~mL}$ of RPMI 1640 supplemented with $10 \%$ bovine fetal serum, $5 \mu \mathrm{L} / \mathrm{mL}$ of phytohemagglutinin, $100 \mathrm{U} / \mathrm{mL}$ of penicillin, $100 \mu \mathrm{L} / \mathrm{mL}$ of streptomycin, and $2 \mathrm{mM}$ of L-glutamine. For each study subject, duplicate cell cultures were set up to determine the spontaneous and BLM-induced CA frequency, respectively. All cultures were incubated at $37^{\circ} \mathrm{C}$ in a thermostat bath for $48 \mathrm{~h}$, and cell division was interrupted by the addition of $0.2 \mu \mathrm{g} / \mathrm{mL}$ of colcemid during the last $2 \mathrm{~h}$.

For the BLM-treated cultures, the BLM was added $5 \mathrm{~h}$ before the end of the $48 \mathrm{~h}$ in sufficient quantities to obtain a final concentration of $12.5 \mu \mathrm{g} / \mathrm{mL}$ in complete medium [22]. The BLM solution employed was prepared by dissolving bleomycin sulfate (Nippon Kayaku Co., Tokyo, Japan, distributed by Novartis Pharma S.p.A, Milan) in bidistilled sterile $\mathrm{H}_{2} \mathrm{O}$. The BLM treatment was not found to be cytotoxic to peripheral lymphocytes, as demonstrated by the Trypan blue cell viability test.

All preparations were set up and stained according to standard procedures [23]. At least 100 metaphases on coded slides were counted and scored blindly for each subject according to the International System for Human Cytogenetic Nomenclature for CAs.

In the analyses of spontaneous CA frequency, the total CAs and the chromosome and chromatid breaks separately were considered, while achromatic lesions (gaps) were not counted as CAs. To assess the BLM-induced frequency of CAs, chromatid breaks were considered, taken as percentage number over the total cells observed, as number of metaphases presenting chromatid breaks and as number of chromatid breaks per cell [24].

\subsection{Analysis of Micronuclei}

The MN analyses were done using the cytokinesis block technique [25]. For each study subject, duplicate cultures were set up to determine the spontaneous and BLM-induced frequency of $\mathrm{MN}$, respectively.

To this end, $2.5 \times 10^{6}$ of peripheral lymphocytes isolated by Histopaque gradient centrifugation were cultured in $5 \mathrm{~mL}$ of RPMI 1640 medium added with fetal bovine serum (15\%), L-glutamine $(1 \mathrm{mM})$, phytohemagglutinin $(1 \%)$, and penicillin-streptomycin $(1 \%)$. The cultures were incubated in a steam-saturated environment at $5 \% \mathrm{CO}_{2}$ for $72 \mathrm{~h}$. After $44 \mathrm{~h}$ from the start of the incubation, the cell cultures were added with cytochalasin B at a final concentration of $6 \mu \mathrm{g} / \mathrm{mL}$ to block cytokinesis. The cultures to be treated with BLM underwent this addition $5 \mathrm{~h}$ before the end of the $72 \mathrm{~h}$, according to the same procedure described above for the CAs.

At the end of the $72 \mathrm{~h}$ of incubation, all the cell cultures underwent hypotonic and fixative treatment according to standard procedures [26]. Then the slides were set up and, after $24 \mathrm{~h}$, stained with 
May-Grunwald- Giemsa and blindly observed at the optical microscope according to standard criteria. For each subject, 2000 binuclear lymphocytes with a well conserved cytoplasm were observed. Both the spontaneous and the BLM-induced frequency of MN were expressed as number of total MN per 1000 cells analyzed.

\subsection{Comet Assay}

Peripheral blood lymphocytes were isolated from the freshly collected samples by a standard method on a Histopaque density gradient. After centrifugation, the buffy coat was washed in PBS; the cells were counted, using the Trypan-Blue exclusion technique, and their viability ( $>98 \%$ ) was determined using fluorescein diacetate/ethidium bromide. The cells were tested in alkaline conditions according to the procedure by Singh et al., as described in detail in previous studies $[27,28]$.

In brief, $10 \mathrm{~mL}$ of lymphocytes suspension were mixed with $75 \mathrm{~mL}$ of agarose at a low fusion point $(0.7 \%)$ and then placed on slides precoated with $100 \mathrm{~mL}$ agarose $(1 \%)$. After solidification of the upper layer of agarose, the slides were accurately immersed for $1 \mathrm{~h}$ at $4{ }^{\circ} \mathrm{C}$ in a freshly prepared lysing solution (2.5 M NaCl, $100 \mathrm{mM}$ EDTA, $10 \mathrm{mM}$ Tris, $\mathrm{pH} 10)$ and then, immediately before analysis, in a solution composed of N-lauroylsarcosine (1\%), DMSO (10\%) and Triton X-100 (1\%). The subsequent phases, namely permanence in an alkaline environment $(\mathrm{pH}>13)$ for $40 \mathrm{~min}$, electrophoresis and neutralization were done according to the standard protocol. After electrophoresis, the slides were neutralized with PBS, cold immersed in $10 \%$ ethanol, and then dried at room temperature and kept in a dry atmosphere for a maximum period of 3 months before analysis.

For each subject, 100 randomly selected cells ( 50 cells for each of the 2 slides) were examined by fluorescence microscopy and the degree of DNA damage was measured using analytic software based on electronic images (Perceptive Instruments, Suffolk, UK). DNA damage quantification was done by evaluating the percentage of DNA in the tail (tail intensity-TI), tail length (tail length-TL), and the product of tail length by tail intensity (tail moment-TM). The median of each parameter was used as representative value for each subject, and the mean of the medians was applied for statistical analyses. Among the three Comet assay parameters determined, TI is currently considered the most useful biomarker for assessing DNA strand breaks, and so this was the one used for subsequent analyses of the results [29].

To identify the presence of oxidized purine and pyrimidine bases, a modified version of the Comet assay was employed, using Formamidopyrimidine glycosylase (Fpg) and Endonuclease III (Endo III), two glycosylases that can operate excision in apurine/apyrimidine sites, respectively, that are then converted to breaks. For each subject, therefore, 2 other slides were prepared and incubated for $30 \mathrm{~min}$ at $37^{\circ} \mathrm{C}$ with $70 \mu \mathrm{L}$ of Fpg or Endo III. At the end of the incubation, the Comet assay was performed as described above. The measures of oxidized bases were obtained by subtracting the Comet values with buffer alone from those with Fpg or Endo III. All these passages were done under yellow light to avoid further DNA damage.

\subsection{Genetic Polymorphisms}

Genetic polymorphisms of the three enzymes involved in different phases of the DNA repair process were investigated: $X R C C 1$, that has a central role in the base excision repair system (BER), for which three different polymorphisms were studied; XRCC3, implicated in the repair of double-strand DNA breaks by homologous recombination (HRR), and XPD that pertains to the nucleotides excision oxidative damage repair system. In addition, the polymorphisms of three enzymes that act on the detoxification of reactive intermediates that can be produced following cell-IR interactions were studied: GSTT1 and GSTM1 of the GST family, and the protease BLHX, also involved in the inactivation of BLM.

To determine genetic polymorphisms, genomic DNA was isolated from a second aliquot of peripheral blood samples collected in EDTA. In brief, DNA isolated from peripheral lymphocytes was purified twice by the addition of $500 \mu \mathrm{L}$ of $70 \%$ ethanol, centrifuged at $+4{ }^{\circ} \mathrm{C}$, dried at room 
temperature for $1 \mathrm{~h}$, and resuspended in $100 \mu \mathrm{L}$ of TE buffer $(10 \mathrm{mM}$ Tris-HCl, $\mathrm{pH} 7.4 ; 1 \mathrm{mM}$ EDTA, $\mathrm{pH}$ 8.0). The DNA samples were diluted, divided in $10 \mathrm{ng} / \mu \mathrm{L}$ aliquots and conserved at $-20^{\circ} \mathrm{C}$ for subsequent amplification by standard polymerase chain reaction (PCR)-based methods. PCR was performed on 10 ng of DNA using HotMaster Taq DNA polymerase (5 PRIME Inc., Gaithersburg, MD, USA) according to the manufacturer's instructions using the following protocol: initial denaturation for $5 \mathrm{~min}$ at $95^{\circ} \mathrm{C}$ followed by 35 cycles lasting $30 \mathrm{~s}$ at $95^{\circ} \mathrm{C}, 30 \mathrm{~s}$ at $\mathrm{Tm}{ }^{\circ} \mathrm{C}$, and $30 \mathrm{~s}$ at $65{ }^{\circ} \mathrm{C}$, and a final extension at $65^{\circ} \mathrm{C}$ for $5 \mathrm{~min}$. Negative and positive controls were used in the PCR reaction for the different genotypes.

Specific primer pairs were designed to selectively amplify XRCC exons 6, 9, and 10, XRCC3 gene exon 7, XPD gene exon 23, and BLMH gene exon 12. The primers sequences and amplification conditions are listed in Table 1. The amplified fragments were digested with the RFLP (restriction fragment length polymorphism) technique using specific Thermo Scientific FastDigest enzymes for each of the polymorphisms studied, according to the manufacturer's instructions (Thermo Scientific, Waltham, MA, USA). After enzymatic digestion, the samples were subjected to electrophoresis in $2 \%$ agarose gel (containing Ethidium Bromide) to allow separation of the bands if the DNA fragment under study had been digested, thus allowing the identification of the presence of polymorphisms.

Table 1. The primers sequences and amplification conditions for the genes investigated.

\begin{tabular}{|c|c|c|c|c|}
\hline Gene & Exon & Primer $\mathbf{F}$ & Primer $\mathbf{R}$ & Annealing Temperature \\
\hline XRCC1 & 6 & TGTACCTGTCACTCCCCATGG & СACTCCTATCTATGGGACACAG & 58 \\
\hline XRCC1 & 9 & TGGGGCCTGGATTGCTGGGTCTG & CAGCACCACTACCACACCCTGAAGG & 62 \\
\hline XRCC1 & 10 & AGTAAGTCTCCGTGGCTCTGG & TCTCCCTTGGTCTCCAACCT & 58 \\
\hline XRCC3 & 7 & GGTCGAGTGACAGTCCAAAC & TGCAACGGCTGAGGGTCTT & 62 \\
\hline$X P D$ & 23 & ССССТСТСССТTTССТСТGTT & GCTGCCTTCTCCTGCGTTA & 61 \\
\hline GSTT1 & 5 & TTCCTTACTGGTCCTCACATCTC & TCACCGGATCATGGCCAGCA & 58 \\
\hline GSTM1 & 6 & GAACTCCCTGAAAAGCTAAAG & GGTTGGGCTCAAATATACGGTGG & 58 \\
\hline$B L X H$ & 12 & GCTGTGTTAGAGCAGGAACCCAATT & CCTGGATCTGTCCTTTGCAGCTCG & 58 \\
\hline
\end{tabular}

The following genes were investigated:

1. Gene XRCC1: Determining the polymorphisms Arg194Trp, Arg280His and Arg399Gln, localized in exons 6, 9, 10, respectively using the respective restriction enzymes PvuII, MspI and RsaI [12,19];

2. Gene XRCC3: Determining the polymorphism Thr241Met, localized on exon 7, using the restriction enzyme NlaIII [12];

3. Gene XPD: Determining the polymorphism Lys751Gln, localized on exon 23, using PstI as restriction enzyme [4];

4. Gene BLMH: Determining the nucleotide substitution (A1450G), using MunI as restriction enzyme.

In regards to analysis of the genotypes GSTM1 and GSTT1, multiplex PCR with the GAPDH fragment was used as internal control, as described by Sanyal et al. [30]. The products of multiplex PCR were visualized under UV light after electrophoresis in $2 \%$ agarose gel containing ethidium bromide.

\subsection{Statistical Analysis}

Statistical analyses were done using the SPSS program (version 14.0, Chicago, IL, USA). The statistical significance for deviation from the Hardy-Weinberg equilibrium (HWE) was determined by $\chi^{2}$-test according to the Guo and Thompson method [31]. For GSTT1 and GSTM1 null genotypes, the HWE could not be tested because the number of heterozygotes is not known. A normal distribution was checked for all variables by Kolmogorov-Smirnov test. Not normally distributed variables were analyzed with parametric tests after logarithmic transformation or with non-parametric tests. The level of significance was set at $p<0.05$. 


\section{Results}

The general characteristics and lifestyle habits were not found to be different when comparing the exposed workers and controls (Table 2). In exposed workers the effective whole body dose of IR in the last year (median: $0.27 \mathrm{mSv}$; range $<0.01-2.46 \mathrm{mSv}$ ) and the cumulative dose over the entire working life (median: $5.31 \mathrm{mSv}$; range: $0.20-54.43 \mathrm{mSv}$ ) were generally very low, both significantly different among the workers divided by the type of job (Table 3).

All the genotypes studied were found to be balanced according to the Hardy-Weinberg equation. No significant differences were found between exposed workers and controls, as regards the frequencies of the polymorphisms studied, except for polymorphism Arg280His of XRCC1 with the Arg/Arg genotype, that was significantly more frequent in the exposed workers $(97.5 \%)$ than the controls $(75 \%)$ $(p=0.007)$ (Table 4).

The frequency of total CAs and spontaneous chromosomal breaks was significantly higher in the exposed workers than the controls $(p<0.05$ and $p<0.01$, respectively), while the frequency of chromatid breaks and spontaneous MN, of all the BLM-induced DNA damage biomarkers, and the three Comet assay parameters, did not seem different between the two groups (Table 5).

The simultaneous influence of occupational exposure and sex, and of cigarette smoking, on the spontaneous and BLM-induced DNA damage biomarkers was verified in exposed workers and controls by two-way analysis of variance. For this purpose, the subjects were subdivided into males versus females, and smokers versus nonsmokers + ex-smokers. No relation was found between occupational exposure, sex, and cigarette smoking and spontaneous and BLM-induced DNA damage biomarkers, except for spontaneous chromosomal breaks, that appeared to be associated with occupational exposure $(p<0.05)$, and for TI and TI Endo III, that showed significantly higher values in females $(p<0.01$ for both comparisons; Table 6).

Study was made of the correlation between biomarkers of spontaneous and BLM-induced genotoxicity and the general characteristics and lifestyle habits, respectively, and, only in the exposed workers, the effective whole body dose of IR in the last year and the cumulative one, in all subjects considered as a single group and then in exposed workers and controls separately. As regards the biomarkers of spontaneous genotoxicity, there was a positive correlation only between the frequency of $\mathrm{MN}$ and age $(\mathrm{r}=0.24, p<0.05)$ in all the subjects considered as a single group. For BLM-induced genotoxicity biomarkers, in all subjects considered as a single group there was a significant negative correlation between the number of cigarettes smoked daily and the frequency of total chromatid breaks $(\mathrm{r}=-0.44, p<0.05)$, the frequency of metaphases with chromatid breaks $(\mathrm{r}=-0.48, p<0.05)$ and the frequency of chromatid breaks per cell $(r=-0.44, p<0.05)$, while for the frequency of metaphases with chromatid breaks only a negative correlation was observed also in the exposed workers $(r=-0.65$, $p<0.05)$.

To verify the influence of polymorphisms of DNA repair and detoxification enzymes on the frequency of spontaneous and BLM-induced DNA damage biomarkers, exposed workers and controls were subdivided into wild-type and carriers of allelic variants in hetero and homozygosis for the enzymes XRCC1, XRCC3, XPD, BLHX, GSTM1, and GSTT1. In particular, for the gene XRCC1, the overall presence of allelic variants for the three polymorphisms studied, namely Arg194Trp, Arg280His, and Arg399Gln was analyzed, subdividing the subjects, both exposed workers and controls, into those who presented no allelic variant for any of the genetic polymorphisms of XRCC1 (wild-type), versus subjects that presented at least one. Statistical comparison, made separately for exposed workers and controls, did not show differences between the wild-type subjects and those with allelic variants for all the parameters considered, with the exception of the frequency of spontaneous MN, that was found to be higher in subjects with allelic variants in XRCC1 as compared to wild-type, but only in the exposed workers group $(p=0.046)$ (Table 7). 
Table 2. General characteristics and lifestyle habits of exposed workers and controls.

\begin{tabular}{|c|c|c|c|c|c|c|c|c|}
\hline \multirow{2}{*}{$\begin{array}{l}\text { General Characteristics } \\
\text { and Lifestyle Habits }\end{array}$} & \multicolumn{4}{|c|}{ EXPOSED WORKERS } & \multicolumn{4}{|c|}{ CONTROLS } \\
\hline & $\mathbf{N}$. & Mean \pm SD & Median & Range & N. & Mean \pm SD & Median & Range \\
\hline Age & 43 & $48.0 \pm 10.6$ & 44.0 & $35.0-75.0$ & 43 & $47.0 \pm 10.4$ & 46.0 & $32.0-68.0$ \\
\hline Work at the job (years) & 43 & $22.0 \pm 11.0$ & 18.0 & $6.0-53.0$ & - & & & \\
\hline BMI & 43 & $24.9 \pm 3.0$ & 25.1 & $18.9-34.2$ & 43 & $25.6 \pm 4.6$ & 25.6 & $17.6-40.6$ \\
\hline \multicolumn{9}{|l|}{ Sex } \\
\hline - Male & 32 & $74.4 \%$ & & & 27 & $62.8 \%$ & & \\
\hline - Female & 11 & $25.6 \%$ & & & 16 & $37.2 \%$ & & \\
\hline \multicolumn{9}{|l|}{ Residence } \\
\hline - Urban & 38 & $88.4 \%$ & & & 41 & $95.3 \%$ & & \\
\hline - Rural & 5 & $11.6 \%$ & & & 2 & $4.7 \%$ & & \\
\hline \multicolumn{9}{|l|}{ Smoking habit } \\
\hline - Non smoker & 20 & $46.5 \%$ & & & 23 & $53.5 \%$ & & \\
\hline - Smoker & 12 & $27.9 \%$ & & & 12 & $27.9 \%$ & & \\
\hline - Ex smoker & 11 & $25.6 \%$ & & & 8 & $18.6 \%$ & & \\
\hline - N. cigarettes/day & 12 & $11.2 \pm 5.8$ & 10.0 & $5.0-20.0$ & 12 & $16.8 \pm 10.0$ & 14.5 & $3.0-40.0$ \\
\hline - Packs/year & 23 & $15.7 \pm 10.0$ & 12.0 & $5.0-44.0$ & 20 & $15.6 \pm 18.0$ & 8.4 & $1.0-76.0$ \\
\hline \multicolumn{9}{|l|}{$\begin{array}{l}\text { Weekly alcohol } \\
\text { consumption }\end{array}$} \\
\hline $\begin{array}{l}\text { - Teetotal/occasional } \\
\text { drinker }\end{array}$ & 23 & $53.0 \%$ & & & 18 & $41.9 \%$ & & \\
\hline - <70 g/week & 6 & $14.0 \%$ & & & 10 & $23.3 \%$ & & \\
\hline - 70-200 g/week & 11 & $26.0 \%$ & & & 11 & $25.6 \%$ & & \\
\hline - >200 g/week & 3 & $7.0 \%$ & & & 4 & $9.3 \%$ & & \\
\hline
\end{tabular}


Table 3. Effective whole body dose in the last year (mSv) and over the entire working life (mSv) in exposed workers by job.

\begin{tabular}{|c|c|c|c|c|c|c|}
\hline \multirow[t]{2}{*}{ Exposed Workers } & \multicolumn{3}{|c|}{$\begin{array}{l}\text { Effective Whole Body Dose in the } \\
\text { Last Year (mSv) }{ }^{a}\end{array}$} & \multicolumn{3}{|c|}{$\begin{array}{l}\text { Cumulative Effective Whole Body Dose } \\
\text { over the Entire Working Life (mSv) }\end{array}$} \\
\hline & N. & Median & Range & N. & Median & Range \\
\hline Industrial Radiographers & 7 & 0.80 & $<0.01-1.93$ & 7 & 20.34 & $5.82-36.53$ \\
\hline Hospital radiology workers & 20 & 0.24 & $<0.01-1.57$ & 20 & 1.07 & $0.20-38.26$ \\
\hline Hospital surgery workers & 12 & 1.07 & $0.03-2.46$ & 12 & 24.24 & $0.49-54.43$ \\
\hline Other hospital workers & 4 & 0.18 & $<0.01-0.67$ & 4 & 7.08 & $0.20-15.63$ \\
\hline Total & 43 & 0.27 & $<0.01-2.46$ & 43 & 5.31 & $0.20-54.43$ \\
\hline
\end{tabular}

Table 4. Distribution in exposed workers and controls of genotypes for DNA repair and detoxification enzymes polymorphisms examined.

\begin{tabular}{|c|c|c|c|c|c|c|c|}
\hline \multirow{2}{*}{ Enzymes } & \multirow{2}{*}{ Genes } & \multirow{2}{*}{ Polymorphisms } & \multirow{2}{*}{ Genotype } & \multicolumn{2}{|c|}{ EXPOSED WORKERS } & \multicolumn{2}{|c|}{ CONTRO S } \\
\hline & & & & N. & $\%$ & N. & $\%$ \\
\hline \multirow{15}{*}{$\begin{array}{l}\text { DNA repair } \\
\text { enzymes }\end{array}$} & \multirow{9}{*}{ XRCC1 } & \multirow{3}{*}{ Arg194Trp } & Arg/Arg & 33 & 82.5 & 36 & 90.0 \\
\hline & & & Arg/Trp & 6 & 15.0 & 4 & 10.0 \\
\hline & & & $\operatorname{Trp} / \operatorname{Trp}$ & 1 & 2.5 & 0 & 0.0 \\
\hline & & \multirow{3}{*}{ Arg280His ${ }^{a}$} & Arg/Arg & 39 & 97.5 & 30 & 75.0 \\
\hline & & & Arg/His & 1 & 2.5 & 9 & 22.5 \\
\hline & & & His/His & 0 & 0.0 & 1 & 2.5 \\
\hline & & \multirow{3}{*}{ Arg399Gln } & Arg/Arg & 18 & 45.0 & 22 & 55.0 \\
\hline & & & Arg/Gln & 14 & 35.0 & 12 & 30.0 \\
\hline & & & $\mathrm{Gln} / \mathrm{Gln}$ & 8 & 20.0 & 6 & 15.0 \\
\hline & \multirow{3}{*}{$X R C C 3$} & \multirow{3}{*}{ Thr241Met } & Thr/Thr & 14 & 35.0 & 11 & 27.5 \\
\hline & & & Thr/Met & 19 & 47.5 & 22 & 55.0 \\
\hline & & & Met/Met & 7 & 17.5 & 7 & 17.5 \\
\hline & \multirow{3}{*}{$X P D$} & \multirow{3}{*}{ Lys751Gln } & Lys/Lys & 13 & 32.5 & 11 & 27.5 \\
\hline & & & Lys/Gln & 13 & 32.5 & 20 & 50.0 \\
\hline & & & Gln/Gln & 14 & 35.0 & 9 & 22.5 \\
\hline \multirow{7}{*}{$\begin{array}{l}\text { Detoxification } \\
\text { enzymes }\end{array}$} & \multirow{3}{*}{ BLHX } & \multirow{3}{*}{ A1450G } & $\mathrm{A} / \mathrm{A}$ & 21 & 52.5 & 16 & 40.0 \\
\hline & & & $\mathrm{A} / \mathrm{G}$ & 17 & 42.5 & 23 & 57.5 \\
\hline & & & G/G & 2 & 5.0 & 1 & 2.5 \\
\hline & \multirow{2}{*}{ GSTT1 } & \multirow{2}{*}{ Deletion } & Non null & 36 & 90.0 & 32 & 80.0 \\
\hline & & & Null & 4 & 10.0 & 8 & 20.0 \\
\hline & \multirow{2}{*}{ GSTM1 } & \multirow{2}{*}{ Deletion } & Non null & 26 & 66.6 & 26 & 66.6 \\
\hline & & & Null & 13 & 33.4 & 13 & 33.4 \\
\hline
\end{tabular}


Table 5. Frequency of spontaneous chromosome aberrations, spontaneous and BLM-induced micronuclei, and the Comet assay parameters in exposed workers and controls.

\begin{tabular}{|c|c|c|c|c|c|c|c|c|}
\hline \multirow{2}{*}{ DNA Damage Markers } & \multicolumn{4}{|c|}{ EXPOSED WORKERS } & \multicolumn{4}{|c|}{ CONTROLS } \\
\hline & N. & $\begin{array}{l}\text { Mean } \pm \\
\text { SD }\end{array}$ & Median & Range & N. & $\begin{array}{l}\text { Mean } \pm \\
\text { SD }\end{array}$ & Median & Range \\
\hline \multicolumn{9}{|l|}{$\begin{array}{l}\text { Chromosome aberrations } \\
\text { frequency }\end{array}$} \\
\hline \multicolumn{9}{|l|}{ Spontaneous } \\
\hline- Total $(\%)^{\mathrm{a}}$ & 41 & $2.8 \pm 1.7$ & 2.0 & $0-6$ & 41 & $2.2 \pm 1.8$ & 1.0 & $0-7$ \\
\hline - Chromatid breaks (\%) & 41 & $2.1 \pm 1.1$ & 2.0 & $0-6$ & 41 & $1.9 \pm 1.5$ & 1.0 & $0-6$ \\
\hline - Chromosome breaks (\%) ${ }^{\mathrm{b}}$ & 41 & $0.8 \pm 1.1$ & 0.0 & $0-4$ & 41 & $0.3 \pm 0.6$ & 0.0 & $0-2$ \\
\hline \multicolumn{9}{|l|}{ BLM-induced } \\
\hline - Chromatid breaks (\%) & 40 & $47.8 \pm 17.6$ & 44.5 & $12-90$ & 40 & $45.8 \pm 16.0$ & 47.5 & $20-80$ \\
\hline $\begin{array}{l}\text { - Metaphases with chromatid } \\
\text { breaks (\%) }\end{array}$ & 40 & $20.1 \pm 5.2$ & 21.5 & $8-32$ & 40 & $19.8 \pm 5.4$ & 20.5 & $8-31$ \\
\hline - Chromatid breaks per cell & 40 & $0.96 \pm 0.35$ & 0.89 & $0.24-1.80$ & 40 & $0.92 \pm 0.32$ & 0.95 & $0.40-1.60$ \\
\hline \multicolumn{9}{|l|}{ Micronuclei (MN) frequency } \\
\hline - Spontaneous (MN/1000 BN) & 43 & $16.2 \pm 9.4$ & 14.0 & $3-45$ & 42 & $14.2 \pm 8.5$ & 12.0 & $4-42$ \\
\hline - BLM-induced (MN/1000 BN) & 41 & $22.3 \pm 9.3$ & 20.0 & $9-51$ & 41 & $25.3 \pm 9.5$ & 24.0 & $7-50$ \\
\hline \multicolumn{9}{|l|}{ Comet assay parameters } \\
\hline - TI (\%) & 43 & $3.0 \pm 1.0$ & 3.4 & $0.9-4.9$ & 43 & $3.2 \pm 1.0$ & 3.4 & $0.9-4.7$ \\
\hline - TI Fpg (\%) & 43 & $3.2 \pm 1.1$ & 3.3 & $1.1-5.0$ & 43 & $3.2 \pm 1.0$ & 3.4 & $0.8-4.8$ \\
\hline - TI Endo III (\%) & 43 & $3.0 \pm 0.9$ & 3.1 & $1.1-4.6$ & 43 & $3.1 \pm 1.0$ & 3.1 & $0.9-5.5$ \\
\hline
\end{tabular}

Table 6. DNA damage markers in workers subdivided by exposure and sex or smoking habit.

\begin{tabular}{|c|c|c|c|c|c|c|c|c|}
\hline \multirow{2}{*}{ DNA Damage Markers } & \multirow{2}{*}{ Variables } & \multicolumn{3}{|c|}{ Exposed } & \multicolumn{3}{|c|}{ Controls } & \multirow{2}{*}{ ANOVA } \\
\hline & & $\mathbf{N}$ & Median & Range & $\mathbf{N}$ & Median & Range & \\
\hline \multirow{3}{*}{$\begin{array}{c}\text { Spontaneous } \\
\text { chromosome breaks (\%) }\end{array}$} & Male & 30 & 0.0 & $0.0-4.0$ & 25 & 0.0 & $0.0-2.0$ & \multirow{2}{*}{$\begin{array}{c}\text { Model: } p=0.047 \\
\text { Sex: NS } \\
\text { Exposure: } p=0.013\end{array}$} \\
\hline & Female & 11 & 1.0 & $0.0-3.0$ & 16 & 0.0 & $0.0-2.0$ & \\
\hline & Smokers & 12 & 0.0 & $0.0-3.0$ & 12 & 0.0 & $0.0-1.0$ & $\begin{array}{c}\text { Model: } p=0.033 \\
\text { Smoke: NS } \\
\text { Exposure: } p=0.010\end{array}$ \\
\hline \multirow[t]{2}{*}{$\mathrm{TI}(\%)$} & Male & 32 & 3.4 & $0.9-4.3$ & 27 & 2.7 & $0.9-4.6$ & \multirow{2}{*}{$\begin{array}{c}\text { Model: } p=0.034 \\
\text { Sex: } p=0.007 \\
\text { Exposure: NS }\end{array}$} \\
\hline & Female & 11 & 3.4 & $1.9-4.9$ & 16 & 3.8 & $2.4-4.7$ & \\
\hline \multirow{2}{*}{ TI Endo III (\%) } & Male & 32 & 2.9 & $1.1-4.6$ & 27 & 2.7 & $0.9-4.9$ & \multirow{2}{*}{$\begin{array}{c}\text { Model: } p=0.014 \\
\text { Sex: } p=0.006 \\
\text { Exposure: NS }\end{array}$} \\
\hline & Female & 11 & 3.3 & $2.0-4.3$ & 16 & 3.6 & $2.4-5.5$ & \\
\hline
\end{tabular}

* Including ex-smokers; NS = not significant; model not significant for sex and smoking habits for total chromosome aberrations (\%), chromatid breaks (\%), micronuclei frequencies/1000 BN, TI Fpg (\%), BLM-induced chromatid breaks $(\%)$, metaphases with chromatid breaks (\%), chromatid breaks per cell; model not significant only for smoking habits for TI (\%) and TI Endo III (\%). 
Table 7. DNA damage markers in exposed and controls divided based on the combination of genetic polymorphisms Arg194Trp, Arg280His, and Arg399Gln of XRCC1.

\begin{tabular}{|c|c|c|c|c|c|c|c|}
\hline \multirow{2}{*}{$\begin{array}{l}\text { DNA Damage } \\
\text { Markers }\end{array}$} & \multirow{2}{*}{$\begin{array}{c}\text { Polymorphism } \\
\text { XRCC1 }\end{array}$} & \multicolumn{3}{|c|}{ Exposed } & \multicolumn{3}{|c|}{ Controls } \\
\hline & & $\mathbf{N}$ & Median & Range & $\mathbf{N}$ & Median & Range \\
\hline \multirow{2}{*}{$\begin{array}{l}\text { Total chromosome } \\
\text { aberrations }(\%)\end{array}$} & wild-type & 11 & 3.0 & $1.0-6.0$ & 13 & 2.0 & $1.0-7.0$ \\
\hline & $\begin{array}{c}\text { one or more allelic } \\
\text { variants }\end{array}$ & 29 & 2.0 & $0.0-6.0$ & 26 & 1.0 & $0.0-6.0$ \\
\hline \multirow{2}{*}{ Chromatid breaks (\%) } & wild-type & 11 & 2.0 & $1.0-3.0$ & 13 & 2.0 & $0.0-6.0$ \\
\hline & $\begin{array}{c}\text { one or more allelic } \\
\text { variants }\end{array}$ & 29 & 2.0 & $0.0-6.0$ & 26 & 1.0 & $0.0-6.0$ \\
\hline \multirow{2}{*}{$\begin{array}{l}\text { Chromosomal breaks } \\
(\%)\end{array}$} & wild-type & 11 & 0.0 & $0.0-4.0$ & 13 & 0.0 & $0.0-2.0$ \\
\hline & $\begin{array}{c}\text { one or more allelic } \\
\text { variants }\end{array}$ & 29 & 0.0 & $0.0-3.0$ & 26 & 0.0 & $0.0-2.0$ \\
\hline \multirow{2}{*}{ Micronuclei/1000BN (\%) } & wild-type & 11 & 11.0 & $3.0-22.0$ & 13 & 12.0 & $5.0-42.0$ \\
\hline & $\begin{array}{c}\text { one or more allelic } \\
\text { variants }\end{array}$ & 29 & 16.0 & $6.0-45.0$ & 26 & 13.0 & $4.0-32.0$ \\
\hline \multirow{2}{*}{ TI (\%) } & wild-type & 11 & 3.5 & $0.9-4.3$ & 13 & 3.1 & $0.9-4.0$ \\
\hline & $\begin{array}{c}\text { one or more allelic } \\
\text { variants }\end{array}$ & 29 & 3.3 & $0.9-4.9$ & 27 & 3.4 & $1.2-4.7$ \\
\hline \multirow{2}{*}{ TI Fpg (\%) } & wild-type & 11 & 3.3 & $1.2-4.9$ & 13 & 3.1 & $0.8-4.8$ \\
\hline & $\begin{array}{c}\text { one or more allelic } \\
\text { variants }\end{array}$ & 29 & 3.2 & $1.1-5.0$ & 27 & 3.3 & $1.2-4.8$ \\
\hline \multirow{2}{*}{ TI Endo III (\%) } & wild-type & 11 & 2.8 & $1.9-4.4$ & 13 & 2.8 & $1.3-4.4$ \\
\hline & $\begin{array}{c}\text { one or more allelic } \\
\text { variants }\end{array}$ & 29 & 3.1 & $1.1-4.6$ & 27 & 3.1 & $0.9-5.5$ \\
\hline
\end{tabular}

Wild-type vs. one or more allelic variants; exposed: Micronuclei $p=0.046$; other indicators not significant; not exposed: All cytogenetic indicators non-significant.

To assess the dependency of the single biomarkers of spontaneous and BLM-induced DNA damage on the independent variables, namely occupational exposure, sex, age, BMI, cigarette smoking, alcohol consumption, and the presence of allelic variants for each of the genetic polymorphisms studied, linear stepwise regression was performed. The results demonstrated a positive dependency of the frequency of spontaneous chromosomal breaks on occupational exposure, and a dependency of the frequency of BLM-induced MN negative on occupational exposure and positive on the consumption of alcohol and on the null GSTM1 genotype (Table 8).

Table 8. Linear stepwise regression to study the dependency of the variables frequency of spontaneous chromosome breaks and frequency of BLM-induced micronuclei on the independent variables' occupational exposure, consumption of alcohol, and GSTM1 polymorphism.

\begin{tabular}{|c|c|c|c|c|c|c|}
\hline \multirow[t]{2}{*}{ Independent Variable } & \multicolumn{3}{|c|}{$\begin{array}{c}\text { Spontaneous Chromosome Breaks } \\
\text { Frequency }(\%)\end{array}$} & \multicolumn{3}{|c|}{$\begin{array}{l}\text { BLM-Induced Micronuclei } \\
\text { Frequency (MN/1000 BN) }\end{array}$} \\
\hline & Beta & & $p$ & & & $p$ \\
\hline \multicolumn{7}{|l|}{ Exposure groups (ref. control) } \\
\hline - exposed workers & 0.28 & & 0.012 & & & 0.033 \\
\hline Alcohol consumption (g/week) & - & & ns & & & 0.001 \\
\hline $\begin{array}{l}\text { GSTM1 (ref. wild-type) } \\
\text { - null }\end{array}$ & - & & ns & & & 0.001 \\
\hline \multirow{2}{*}{ Model } & $F$ & $p$ & $R^{2}$ & $F$ & $p$ & $R^{2}$ \\
\hline & 6.55 & 0.012 & 0.07 & 5.85 & 0.001 & 0.16 \\
\hline
\end{tabular}

Other independent variables not found to be significant: age, sex, BMI, cigarette smoking habit, presence of allelic variants for the genetic polymorphisms of the enzymes XRCC1, XRCC3, XPD, BLHX, GSTT1; ns = not significant. 


\section{Discussion}

This study showed that occupational exposure, even to very low doses, of IR can cause an increased frequency of spontaneous chromosomal breaks and induce an increased frequency of spontaneous MN in subjects with at least one allelic variant of the XRCC1 gene. Moreover, analysis of the individual mutagen sensitivity demonstrated a dependency of BLM-induced MN frequency negative on IR exposure, and positive on the null GSTM1 genotype and on alcohol consumption.

Occupational exposure to IR has progressively reduced in the last 30 years, as safer radiogenic machines emitting less IR have replaced earlier, less safe equipment. Italian law for the health and safety of workers exposed to IR is detailed in legislative decree n. 230 of 1995 and subsequent modifications and integrations derived from European Union norms and those of the International Commission on Radiological Protection. The limit value of the annual effective whole body dose for workers exposed to IR is set at $20 \mathrm{mSv}$, and for the general population at $1 \mathrm{mSv}$. The cumulative occupational exposure found in our examined workers showed a median value of $5.31 \mathrm{mSv}$, with a range of $0.20-54.43 \mathrm{mSv}$, so apparently very low.

Although the workers were exposed to very low doses of $I R$, an increased frequency of chromosome but not of chromatid breaks was observed in the exposed workers group, similar to that observed by Zakeri et al. [32] and Maffei et al. [6] in workers exposed to higher doses of IR. The increased chromosome breaks in the workers examined, but without the presence of ring or dicentric chromosomes, can be explained by the fact that very low doses of IR may not be sufficient to produce the two independent chromosomal breaks necessary to form more complex alterations. Moreover, it should be considered that the DNA double-strand breaks induced by exposure to IR could trigger a recombinogenic exchange that, if incomplete, appears in metaphase as a chromatid break [33]. However, this mechanism is activated only at exposure to higher doses than those found in our study [6].

Previous studies showed an increased frequency of spontaneous MN in health care workers exposed to mean cumulative doses of IR ranging from 19.49 to $40.61 \mathrm{mSv}$, but without observing any relation to the duration of exposure and the IR dose [4,34]. In our study, instead, in workers exposed to much lower doses of IR, no increase in the frequency of spontaneous MN was observed, as also reported by Touil et al. [35], even if their workers were exposed to a much higher mean cumulative dose than that observed in our study, equal to $82.3 \mathrm{mSv}$.

The absence of a greater frequency of $\mathrm{MN}$ in the examined workers could depend on their exposure only to very low doses of IR. The genotoxic damage determined by such doses would, in fact, be neutralized by the activation of apoptosis mechanisms of the cells damaged during replication in vivo and by the induction of DNA repair enzymes transcription until the saturation of the receptor sites occurs [35-37]. These mechanisms would be more evident for MNs than for chromosomal breaks, because the former are to be regarded as unstable aberrations and so they undergo a clear decline thanks to the activation of the mechanisms previously reported [38].

The Comet assay parameters did not reveal higher values in the workers exposed to IR than the controls. Previous studies of the effects of IR by the Comet assay, in any case using biomarkers other than TI, elicited discordant results whereby some showed an increase $[15,39,40]$ and others no effect $[7,14,32]$. Because the Comet assay reveals recent DNA damage occurring in lymphocytes after exposure to IR, the fact that this was not observed in the exposed workers seems to indicate that the very low doses to which they were chronically exposed are not able to cause an effect detectable by this test, also because of a possible short term up-regulation of the DNA repair capacity induced by the very low IR doses [7,41].

At the cumulative doses of IR exposure, no influence of the polymorphisms studied was found on the frequency of spontaneous CAs and MN and on the Comet assay parameters, with the exception of an increase in the frequency of $\mathrm{MN}$ in the exposed workers bearing one or simultaneously more allelic variants of the three XRCC1 polymorphisms. Previous studies of XRCC1 polymorphisms in workers exposed to IR did not generally reveal any influence of XRCC1 399 and XRCC1 194, analyzed singly, on the frequency of spontaneous MN [12,42,43]. Therefore, the genetic susceptibility to low doses to IR 
could be influenced by the interaction of effects of different enzymatic genetic polymorphisms. The lack of genetic susceptibility observed in our study could also depend on the small number of individuals carrying each allelic variant, that did not allow combined analysis of interactions among the different genes involved, except for the activity of XRCC1, nor a separate analysis of the presence of polymorphic alleles in homozygosis or heterozygosis that could have a different effect on the enzymatic phenotype.

In the exposed workers, individual mutagen sensitivity was not shown in our study, in agreement with other authors, a reduction in BLM-induced clastogenic damage, unlike what was observed by Barquinero et al. [16] for exposure to higher doses of IR (mean exposure $4.46 \mathrm{mSv} /$ year, range 0-28 mSv/year) $[17,44]$. Nevertheless, in our work a negative dependency was found of the frequency of BLM-induced MN on chronic exposure to low doses of IR, associated with a positive dependency determined by the presence of the GSTM1 null genotype and of a lifestyle factor such as alcohol consumption. In fact, both these factors determine an increased frequency of BLM-induced MN and seem to be able to make an opposite effect in respect to that induced by IR. The influence of the A1450G polymorphism of BLHX on individual mutagen sensitivity in subjects exposed to IR was also analyzed. Unexpectedly, the results did not show any influence of this polymorphism, unlike the findings by Maffei et al. [6], who had observed an increased frequency of BLM-induced MN in 45 healthy subjects, nonsmokers, with no genotoxic exposure, who were carriers of the allelic variant of the above BLHX polymorphism in homozygosis or heterozygosis.

Cigarette smoking was not found to affect the frequency of spontaneous CAs and MN. This could be due to the small number of heavy smokers among our exposed workers and controls, since it has been demonstrated in the literature that an increased frequency of $\mathrm{MN}$ is present only in smokers of more than 30 cigarettes/day [45]. Nor was any relation between smoking habit and the Comet assay parameters found, in partial agreement with the literature, although discordant results have also been reported [40]. Indeed, our results did not show an interaction between exposure to IR and a smoking habit in determining either spontaneous or BLM-induced genotoxic damage, unlike what was observed by other authors in workers exposed to higher doses of IR [16,35,44]. Instead, the cytogenetic biomarkers of BLM-induced chromatid breakage were all found to be negatively correlated with the number of cigarettes/day, whereas no correlation was found with the number of packets/year. This finding; however, seems to indicate that the daily smoking habit may have the effect to increase the DNA repair efficiency, independently from exposure to IR.

When analyzing the exposed workers and controls as a single group, a positive correlation was found between the frequency of spontaneous $\mathrm{MN}$ and age, in agreement with reports in literature [45]. Age is naturally a factor that can influence the frequency of $\mathrm{MN}$ in peripheral lymphocytes as a consequence both of the cumulative effects of acquired gene mutations involving DNA repair and cell replication mechanisms, and of the progressive accumulation of chromosome damage caused by exposure to endogenous and environmental genotoxic substances [46].

Sex was not shown to have an influence on any of the biomarkers studied, with the exception of TI and TI Endo III, whose values were significantly higher in the females studied, although there were far fewer females than males among our exposed workers and controls. The relation between sex and the Comet assay parameters is still controversial, and discordant results have been reported in different studies [47].

\section{Conclusions}

In conclusion, our results demonstrate that even very low doses of IR can provoke genotoxic damage, revealed by the increased frequency of chromosomal breaks. Genetic polymorphisms of the DNA repair enzymes and detoxification enzymes, instead, do not seem to affect the onset of damage induced by IR if considered singly, so it seems evident that it is the influence of more allelic variants that needs to be assessed, as done in our study for XRCC1. Finally, the results on the frequency of BLM-induced $\mathrm{MN}$ offer the first evidence of a complex interaction between exposure to very low doses of IR, individual genetic factors, and environmental factors connected to the individual's lifestyle, 
in determining individual mutagen sensitivity. This confirms that the effect of very low doses of IR can only be properly studied in the wider context of associations among many factors that can interfere with or modulate the DNA damage.

Author Contributions: P.L. and A.S. designed the study, with the contribution of C.L., V.R., I.D. and L.S.; A.S., P.L. and L.V. recruited the participants and collected the data. P.C. and L.D.B. performed the cytogenetic analyses and the mutagen sensitivity assay; R.B. and N.R. performed the study of the polymorphisms; I.D. performed statistical analyses with the contribution of P.L. and A.S.; A.S. and P.L. prepared the manuscript draft with important intellectual input from all the other authors; L.S., C.L. and V.R. revised the manuscript draft and supervised the study. All the authors approved the final manuscript.

Funding: This research received no external funding.

Conflicts of Interest: The authors declare no conflict of interest.

\section{References}

1. International Atomic Energy Agency. Cytogenetic Analysis for Radiation Dose Assessment: A Manual; Technical Reports Series No. 405; IAEA: Vienna, Austria, 2001; p. 13.

2. IARC. Radiation Monographs on the Evaluation of Carcinogenic Risks to Humans; World Health Organization: Lyon, France, 2012; Volume 100D, p. 103.

3. Gourabi, H.; Mozdarani, H. A cytokinesis-blocked micronucleus study of the radioadaptive response of lymphocytes of individuals occupationally exposed to chronic doses of radiation. Mutagenesis 1998, 13, 475-480. [CrossRef] [PubMed]

4. Angelini, S.; Kumar, R.; Carbone, F.; Maffei, F.; Forti, G.C.; Violante, F.S.; Lodi, V.; Curti, S.; Hemminki, K.; Hrelia, P. Micronuclei in humans induced by exposure to low level of ionizing radiation: Influence of polymorphisms in DNA repair genes. Mutat. Res. 2005, 15, 105-117. [CrossRef] [PubMed]

5. Milić, M.; Rozgaj, R.; Kašuba, V.; Jazbec, A.M.; Starčević, B.; Lyzbicki, B.; Ravegnini, G.; Zenesini, C.; Musti, M.; Hrelia, P.; et al. Polymorphisms in DNA repair genes: Link with biomarkers of the CBMN cytome assay in hospital workers chronically exposed to low doses of ionising radiation. Arh. Hig. Rada Toksikol. 2015, 66, 109-120. [CrossRef] [PubMed]

6. Maffei, F.; Angelini, S.; Forti, G.C.; Violante, F.S.; Lodi, V.; Mattioli, S.; Hrelia, P. Spectrum of chromosomal aberrations in peripheral lymphocytes of hospital workers occupationally exposed to low doses of ionizing radiation. Mutat. Res. 2004, 22, 91-99. [CrossRef] [PubMed]

7. Güerci, A.M.; Grillo, C.A.; Dulout, F.N.; Seoane, A.I. Assessment of genotoxic damage in lymphocytes of hospital workers exposed to ionizing radiation in Argentina. Arch. Environ. Occup. Health 2006, 61, 163-169. [CrossRef] [PubMed]

8. Kopjar, N.; Garaj-Vrhovac, V. Assessment of DNA damage in nuclear medicine personnel-Comparative study with the alkaline comet assay and the chromosome aberration test. Int. J. Hyg. Environ. Health 2005, 208, 179-191. [CrossRef]

9. Kruszewski, M.; Wojewódzka, M.; Iwanenko, T.; Collins, A.R.; Szumiel, I. Application of the comet assay for monitoring DNA damage in workers exposed to chronic low-dose irradiation: II. Base damage. Mutat. Res. 1998, 7, 37-57. [CrossRef]

10. Maluf, S.W.; Passos, D.F.; Bacelar, A.; Speit, G.; Erdtmann, B. Assessment of DNA damage in lymphocytes of workers exposed to X-radiation using the micronucleus test and the comet assay. Environ. Mol. Mutagen. 2001, 38, 311-315. [CrossRef]

11. Wojewódzka, M.; Kruszewski, M.; Iwaneñko, T.; Collins, A.R.; Szumiel, I. Application of the comet assay for monitoring DNA damage in workers exposed to chronic low-dose irradiation: I. Strand breakage. Mutat. Res. 1998, 7, 21-35. [CrossRef]

12. Andreassi, M.G.; Foffa, I.; Manfredi, S.; Botto, N.; Cioppa, A.; Picano, E. Genetic polymorphisms in XRCC1, OGG1, APE1 and XRCC3 DNA repair genes, ionizing radiation exposure and chromosomal DNA damage in interventional cardiologists. Mutat. Res. 2009, 18, 57-63. [CrossRef]

13. Norppa, H. Genetic susceptibility, biomarker responses, and cancer. Mutat. Res. 2003, 544, 339-348. [CrossRef] [PubMed]

14. Marcon, F.; Andreoli, C.; Rossi, S.; Verdina, A.; Galati, R.; Crebelli, R. Assessment of individual sensitivity to ionizing radiation and DNA repair efficiency in a healthy population. Mutat. Res. 2003, 10, 1-8. [CrossRef] 
15. Sakly, A.; Gaspar, J.F.; Kerkeni, E.; Silva, S.; Teixeira, J.P.; Chaari, N.; Ben Cheikh, H. Genotoxic damage in hospital workers exposed to ionizing radiation and metabolic gene polymorphisms. J. Toxicol. Environ. Health A 2012, 75, 934-946. [CrossRef] [PubMed]

16. Barquinero, J.F.; Barrios, L.; Caballín, M.R.; Miró, R.; Ribas, M.; Subias, A.; Egozcue, J. Occupational exposure to radiation induces an adaptive response in human lymphocytes. Int. J. Radiat. Biol. 1995, 67, $187-191$. [CrossRef] [PubMed]

17. Bolzán, A.D.; Bianchi, M.S.; Giménez, E.M.; Flaqué, M.C.; Ciancio, V.R. Analysis of spontaneous and bleomycin-induced chromosome damage in peripheral lymphocytes of long-haul aircrew members from Argentina. Mutat. Res. 2008, 1, 64-79. [CrossRef]

18. Benkhaled, L.; Xunclà, M.; Caballín, M.R.; Barrios, L.; Barquinero, J.F. Induction of complete and incomplete chromosome aberrations by bleomycin in human lymphocytes. Mutat. Res. 2008, 1, 134-141. [CrossRef]

19. Tuimala, J.; Szekely, G.; Gundy, S.; Hirvonen, A.; Norppa, H. Genetic polymorphisms of DNA repair and xenobiotic-metabolizing enzymes: Role in mutagen sensitivity. Carcinogenesis 2002, 23, 1003-1008. [CrossRef]

20. Angelini, S.; Kumar, R.; Carbone, F.; Bermejo, J.L.; Maffei, F.; Cantelli-Forti, G.; Hemminki, K.; Hrelia, P. Inherited susceptibility to bleomycin-induced micronuclei: Correlating polymorphisms in GSTT1, GSTM1 and DNA repair genes with mutagen sensitivity. Mutat. Res. 2008, 1,90-97. [CrossRef]

21. Wang, Y.; Spitz, M.R.; Zhu, Y.; Dong, Q.; Shete, S.; Wu, X. From genotype to phenotype: Correlating XRCC1 polymorphisms with mutagen sensitivity. DNA Repair 2003, 12, 901-908. [CrossRef]

22. Hsu, T.C.; Johnston, D.A.; Cherry, L.M.; Ramkissoon, D.; Schantz, S.P.; Jessup, J.M.; Winn, R.J.; Shirley, L.; Furlong, C. Sensitivity to genotoxic effects of bleomycin in humans: Possible relationship to environmental carcinogenesis. Int. J. Cancer 1989, 43, 403-409. [CrossRef]

23. The National Foundation. An International System for Human Cytogenetic Nomenclature; Karger: Stockholm, Sweden, 1978; Volume XIV, pp. 51-76.

24. Bolzán, A.D.; Bianchi, M.S. DNA and chromosome damage induced by bleomycin in mammalian cells: An update. Mutat. Res. 2018, 775, 51-62. [CrossRef] [PubMed]

25. Fenech, M.; Morley, A.A. Measurement of micronuclei in lymphocytes. Mutat. Res. 1985, 147, $29-36$. [CrossRef]

26. Maffei, F.; Fimognari, C.; Castelli, E.; Stefanini, G.F.; Forti, G.C.; Hrelia, P. Increased cytogenetic damage detected by FISH analysis on micronuclei in peripheral lymphocytes from alcoholics. Mutagenesis 2000, 15, 517-523. [CrossRef] [PubMed]

27. Singh, N.P.; McCoy, M.T.; Tice, R.R.; Schneider, E.L. A simple technique for quantitation of low levels of DNA damage in individual cells. Exp. Cell Res. 1988, 175, 184-191. [CrossRef]

28. Fracasso, M.E.; Doria, D.; Franceschetti, P.; Perbellini, L.; Romeo, L. DNA damage and repair capacity by comet assay in lymphocytes of white-collar active smokers and passive smokers (non- and ex-smokers) at workplace. Toxicol. Lett. 2006, 1, 131-141. [CrossRef]

29. Collins, A.R.; El Yamani, N.; Lorenzo, Y.; Shaposhnikov, S.; Brunborg, G.; Azqueta, A. Controlling variation in the comet assay. Front. Genet. 2014, 20, 359. [CrossRef]

30. Sanyal, S.; Festa, F.; Sakano, S.; Zhang, Z.; Steineck, G.; Norming, U.; Wijkström, H.; Larsson, P.; Kumar, R.; Hemminki, K. Polymorphisms in DNA repair and metabolic genes in bladder cancer. Carcinogenesis 2004, 25, 729-734. [CrossRef]

31. Guo, S.W.; Thompson, E.A. Performing the exact test of Hardy-Weinberg proportion for multiple alleles. Biometrics 1992, 48, 361-372. [CrossRef]

32. Zakeri, F.; Hirobe, T.; Akbari Noghabi, K. Biological effects of low-dose ionizing radiation exposure on interventional cardiologists. Occup. Med. 2010, 60, 464-469. [CrossRef]

33. Bryant, P.E.; Finnegan, C.E.; Swaffield, L.; Mozdarani, H. G2 chromatid breaks in murine SCID cells. Mutagenesis 1998, 13, 481-485. [CrossRef]

34. Ropolo, M.; Balia, C.; Roggieri, P.; Lodi, V.; Nucci, M.C.; Violante, F.S.; Silingardi, P.; Colacci, A.; Bolognesi, C. The micronucleus assay as a biological dosimeter in hospital workers exposed to low doses of ionizing radiation. Mutat. Res. 2012, 30,7-13. [CrossRef] [PubMed]

35. Touil, N.; Aka, P.V.; Buchet, J.P.; Thierens, H.; Kirsch-Volders, M. Assessment of genotoxic effects related to chronic low level exposure to ionizing radiation using biomarkers for DNA damage and repair. Mutagenesis 2002, 17, 223-232. [CrossRef] [PubMed] 
36. Bauchinger, M. Quantification of low-level radiation exposure by conventional chromosome aberration analysis. Mutat. Res. 1995, 339, 177-189. [CrossRef]

37. Sari-Minodier, I.; Orsière, T.; Bellon, L.; Pompili, J.; Sapin, C.; Botta, A. Cytogenetic monitoring of industrial radiographers using the micronucleus assay. Mutat. Res. 2002, 26, 37-46. [CrossRef]

38. Buckton, K.E.; Brown, W.M.; Smith, P.G. Lymphocyte survival in men treated with x-rays for ankylosing spondylitis. Nature 1967, 29, 470-473. [CrossRef] [PubMed]

39. Garaj-Vrhovac, V.; Kopjar, N. The alkaline Comet assay as biomarker in assessment of DNA damage in medical personnel occupationally exposed to ionizing radiation. Mutagenesis 2003, 18, 265-271. [CrossRef]

40. Gerić, M.; Popić, J.; Gajski, G.; Garaj-Vrhovac, V. Cytogenetic status of interventional radiology unit workers occupationally exposed to low-dose ionising radiation: A pilot study. Mutat. Res. 2019, 843, 46-51. [CrossRef]

41. Gaetani, S.; Monaco, F.; Bracci, M.; Ciarapica, V.; Impollonia, G.; Valentino, M.; Tomasetti, M.; Santarelli, L.; Amati, M. DNA damage response in workers exposed to low-dose ionising radiation. Occup. Environ. Med. 2018, 75, 724-729. [CrossRef]

42. Shakeri, M.; Zakeri, F.; Changizi, V.; Rajabpour, M.R.; Farshidpour, M.R. Cytogenetic effects of radiation and genetic polymorphisms of the XRCC1 and XRCC3 repair genes in industrial radiographers. Radiat. Environ. Biophys. 2019, 58, 247-255. [CrossRef]

43. Cho, Y.H.; Kim, Y.J.; An, Y.S.; Woo, H.D.; Choi, S.Y.; Kang, C.M.; Chung, H.W. Micronucleus-centromere assay and DNA repair gene polymorphism in lymphocytes of industrial radiographers. Mutat. Res. 2009, 680, 17-24. [CrossRef]

44. Dias, F.L.; Antunes, L.M.; Rezende, P.A.; Carvalho, F.E.; Silva, C.M.; Matheus, J.M.; Oliveira, J.V., Jr.; Lopes, G.P.; Pereira, G.A.; Balarin, M.A. Cytogenetic analysis in lymphocytes from workers occupationally exposed to low levels of ionizing radiation. Environ. Toxicol. Pharmacol. 2007, 23, 228-233. [CrossRef] [PubMed]

45. Bonassi, S.; Neri, M.; Lando, C.; Ceppi, M.; Lin, Y.P.; Chang, W.P.; Holland, N.; Kirsch-Volders, M.; Zeiger, E.; Fenech, M. HUMN collaborative group. Effect of smoking habit on the frequency of micronuclei in human lynphocytes: result from the Human MicroNucleus project. Mutat. Res. 2003, 543, 155-166. [CrossRef]

46. Fenech, M.; Holland, N.; Zeiger, E.; Chang, W.P.; Burgaz, S.; Thomas, P.; Bolognesi, C.; Knasmueller, S.; Kirsch-Volders, M.; Bonassi, S. The HUMN and HUMNxL international collaboration projects on human micronucleus assays in lymphocytes and buccal cells—past, present and future. Mutagenesis 2011, 26, 239-245. [CrossRef] [PubMed]

47. Møller, P.; Knudsen, L.E.; Loft, S.; Wallin, H. The comet assay as a rapid test in biomonitoring occupational exposure to DNA-damaging agents and effect of confounding factors. Cancer Epidemiol. Biomarkers. Prev. 2000, 9, 1005-1015.

(C) 2019 by the authors. Licensee MDPI, Basel, Switzerland. This article is an open access article distributed under the terms and conditions of the Creative Commons Attribution (CC BY) license (http://creativecommons.org/licenses/by/4.0/). 